Türkben, T. (2019). Türkçe ders kitaplarındaki metinlerin ilettiği değerler açısından incelenmesi. Ana Dili Eğitimi Dergisi, 7(3), 508-526.

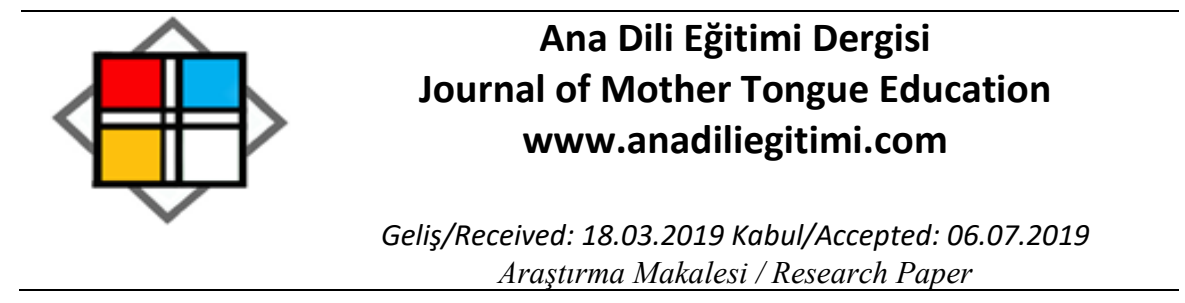

\title{
Türkçe Ders Kitaplarındaki Metinlerin İlettiği Değerler Açısından İncelenmesi
}

\author{
Tuncay TÜRKBEN*
}

\section{Öz}

Değerlerimiz ve yetkinliklerle bütünleşmiş bilgi, beceri ve davranışlara sahip nitelikli bireylerin yetişmesinde Türkçe ders kitabı metinlerinin katkısı yadsınamaz. Öğretim programlarının perspektifini oluşturan değerlerin öğrencilere aktarılmasında bu metinler, temel araç konumundadır. Bu çalışmada, 2018 yılı Türkçe Dersi Öğretim Programı doğrultusunda hazırlanmış Türkçe ders kitapları, değerler iletimi açısından incelenmiştir. Araştırmada nitel araştırma yöntemlerinden doküman analizi kullanılmıştır. Metinler, oluşturulan "Değerler İnceleme Formu"na göre taranmıştır. Elde edilen bulgular tablolar halinde verilmiştir. Elde edilen bulgulara göre metinlerin değerleri iletmede yetersiz kaldığı görülmektedir. Türkçe ders kitapları metinleri arasında değerler iletimi açısından bir dengenin olmadığı tespit edilmiştir. Benzer şekilde ders kitaplarındaki değerlerin dağılımında da bir dengenin gözetilmediği görülmektedir. Ders kitaplarındaki metinlerde en fazla sevgi, saygı, yardımlaşma, duyarlılık, çalışkanlık, dayanışma değerleri yer alırken; en az iletilen değerlerin ise tasarruf, eşitlik, adalet olduğu tespit edilmiştir. Elde edilen bulgular, alanyazından elde edilen bulgularla birlikte değerlendirilmiştir. Araştırmanın bulguları doğrultusunda birtakım önerilere de yer verilmiştir.

Anahtar Kelimeler: Türkçe öğretimi, Türkçe ders kitabı, Metin, Değerler İletimi, İnceleme.

\section{Examining Values in Texts of Turkish Coursebooks}

\begin{abstract}
The contribution of Turkish coursebook texts to the education of qualified individuals who have knowledge, skills and behaviors integrated with our values and competencies cannot be denied. These texts are the primary means of transferring the values that constitute the perspective of the curriculum to the students. In this study, Turkish coursebooks prepared in line with the 2018 Turkish Language Teaching Program were examined in terms of transmission of values. In the study, document analysis, one of the qualitative research methods, was used. The texts were scanned according to the created Values Review Form. The findings are given in tables. According to the findings, it is seen that the texts are insufficient to transmit the values. It was determined that there is no balance between the values of the Turkish coursebooks. Similarly, a balance is not observed in the distribution of the values in the coursebooks. Most of the texts in the coursebooks include love, respect, cooperation, sensitivity, diligence and solidarity. The least transmitted values were found to be savings, equality, and justice. The findings were evaluated together with the findings obtained from the literature. In accordance with the findings of the study, some suggestions were given.
\end{abstract}

Keywords: Turkish teaching, Turkish text books, Text, Values Transfer, Review.

\footnotetext{
* Dr. Öğr. Üyesi, Aksaray Üniversitesi, Eğitim Fakültesi, Türkçe ve Sosyal Bilimler Eğitimi Bölümü, Aksaray, tuncayturkben57@gmail.com, ORCID: 0000-0003-0167-4173
} 


\section{Giriş}

Türkçe öğretimi, öğrencilerin anlama ve anlatma becerilerini geliştirmenin yanında, öğrenme öğretme süreçlerindeki çağdaş öğretim yaklaşımları, yöntem ve tekniklerden yararlanarak ulusal bilinç edinmelerini ve evrensel değerleri içselleştirmelerini amaçlar. Türkçe Dersi Öğretim Programı́nda (TDÖP, 2018) da, günümüz dünyasında bilgiyi üreten, hayatta işlevsel olarak kullanabilen, problem çözebilen, eleştirel düşünen, girişimci, kararlı, iletişim becerilerine sahip, empati yapabilen, topluma ve kültüre katkı sağlayan vb. nitelikte bireylerin yetişmesinin gerekliliği ortaya konmaktadır.

Öğretim programının perspektifine bakıldığında da değerlerimiz ve yetkinliklerle bütünleşmiş bilgi beceri ve davranışlara sahip bireylerin yetiştirilmek istendiği görülmektedir. Bir toplumun geleceği, değerlerini benimseyen ve bu değerleri sahip olduğu yetkinliklerle birlikte kullanan bireylerin yetişmesine bağıı olduğu bir gerçektir. Eğitim programlarında bu değerlerin öğrenciye kazandırılması ayrı bir öğrenme alanı olarak değil öğretim programları, öğrenme öğretme ortamları, eğitim araç gereçleri, ders dışı etkinlikler, mevzuat gibi eğitimin tüm unsurları göz önünde bulundurularak oluşturulmaktadır. Programda adalet, dostluk, dürüstlük, öz denetim, sabır, sorumluluk, vatanseverlik, yardım severlik gibi kök değerlerin öğrenme öğretme sürecinde hem kendi başlarına hem de ilişkili olduğu alt değerlerle birlikte verilmesi amaçlanmaktadır (TDÖP, 2018). Değerler, insanın tüm yaşamı boyunca davranışlarını yönlendiren ve yaşamının şekillenmesinde etkili olan ögelerdir. Eğitim sürecinde, özellikle bilişsel davranışların kazanımına önem verilmekte, duyuşsal özelikler, kazanılmaları açısından hem daha uzun süre gerektirdiğinden hem de bu tür özelikleri kazandırmanın ve gözlemlemenin nispeten güç olmasından dolayı göz ardı edilmektedir (İşcan, 2007, s.75). Bacanlı (1999) eğitimde duyuşsal boyutun ihmal edilmesi, insanların sahip olduğu önemli bir potansiyelin kullanılmamasını doğuracağını belirtmektedir.

Değerler; inanılan, arzu edilen ve davranışlar için bir ölçek olarak kullanılan olgulardır (Öztürk Samur, 2011, s.11). Değer, Latincede "kıymetli olmak" ya da "güçlü olmak" anlamlarına gelen "valere" kökünden türemiştir. Bu kavramın ilk defa sosyal bilimler alanında, Znaniecki tarafından kullanıldığı bilinmektedir (Bilgin, 1995, s.83). Öncül (2000, s.281) değer kavramını, "genel olarak bir nesneye, varlığa ya da faaliyete ruhsal, ahlaksal, toplumsal açıdan ya da estetik yönden tanınan önem veya üstünlük derecesi” şeklinde tanımlamaktadır. TDK Türkçe Sözlük'te de “Bir şeyin önemini belirlemeye yarayan soyut ölçü, bir şeyin değdiği karşlık, kıymet (TDK, 2011, s.607) olarak tanımlanmaktadır. Kurtdede-Fidan ve Öner'e $(2018$, s.3) göre değerler, ulaşılması gereken ideallerdir.

Alanyazın incelendiğinde değerlerin sınıflandırılmasında farklılıkların bulunduğu görülmektedir. Değerler konusunda en iyi bilenen gruplamalardan biri, Spranger (2001) tarafından yapılmıştır. Spranger değerleri; kuramsal, ekonomik, estetik, sosyal, politik ve dini değerler olarak 
gruplandırmıştır (Akbaş, 2004, s.30-31). Lickona ise (1991), yukarıda belirtilen bu değerleri biraz daha artırmıştır. Bunlar: Sorumluluk, saygı, tolerans/hoşgörü, sağduyu, kendini, alışkanlık ve hareketlerini denetim altında tutma, yardımseverlik, merhamet, işbirliği, cesaret, dürüstlük, doğruluk ve demokratik değerler. Rokeach (1973) değerleri amaç (kişisel ve sosyal değerler) ve araç (ahlaki değerler ve sosyal değerler olarak sınıflandırmaktadır (İşcan, 2007, s.22-23). Schwartz (1992) ise değerleri kapsamlı bir şekilde değerlendirmiştir. Bunları da; güç, başarı, hazcılık, uyarım, öz denetim, evrensellik, iyilikseverlik, geleneksellik, uyum, güvenlik, manevilik şeklinde sıralamıştır.

Bir toplumun hayatını şekillendirmesi ve varlığını devam ettirmesinde değerlerin kuşaktan kuşağa aktarılmasının önemi büyüktür (Tulunay Ateş, 2017, s.42). Izgar’a (2013, s.2) göre değerler, toplumdaki bireyleri bir arada tutan en önemli etmenlerdir. Bu nedenle, değerlerin bilinçli, programlı bir şekilde aktarılmasında eğitimin önemi yadsınamaz. Öğrenme öğretme ortamlarında kullanılacak her türlü materyalin de bu doğrultuda özenle hazırlanması gerekmektedir. Öğrenme ortamlarında öğrencilere bilgi ve beceriler kazandırılırken istendik ulusal ve evrensel değerlerin de öğrencilere aktarılması önem arz etmektedir.

Öğrenme öğretme süreçlerinde kullanılan ders kitaplarının önemi daha da fazladır. Ders kitapları ülke genelinde her öğrenciye ulaştı̆̆ı için bu kitapların biçimsel, içerik ve eğitsel değerler açısından özenle hazırlanmalıdır. Metinler, çocuğa görelik ilkesi doğrultusunda seçilmelidir. Bu metinler aracılığıyla dil becerileri geliştirilmesi ile birlikte değerler aktarımının yapılması da hedeflenmelidir. Şen'e (2008, s.765) göre Türkçe ders kitaplarında Türkçenin doğru, güzel, estetik bir şekilde kullanıldığı ve bildirişim yönü kuvvetli metinler kullanılmalıdır. Bu metinlerle dil bilinci ve duyarlılığı kazandırılabileceği gibi insanî, ahlaki, manevî ve kültürel değerler de öğrencilere kazandırılabilir. Sever, Kaya ve Aslan'a (2013, s.12-13) göre düşünen ve duyarlı bireylerin yetişmesi, zengin uyaranlı eğitim ortamlarında çocuklar için yazılmış yapıtların öğretim aracı olarak kullanılmasına bağılıdr. Bu yapıtlar aracılığıyla amaçlanan becerilerin kazandırılması mümkün olduğu gibi; ulusal bilinç edinmiş, evrensel değerlerle barışık, iletişim becerileri gelişmiş, yazııı kültürle etkili bir iletişime girebilen, düşünen duyarlı bireylerin yetişmesi de mümkün olabilecektir.

Alanyazın incelendiğinde, Türkçe ders kitaplarındaki metinler üzerine yapılan çalışmaların olduğu görülmektedir. Şen (2008) altıncı sınıf Türkçe ders kitaplarındaki metinleri ilettiği değerler açısından incelemiştir. Ders kitaplarında yer alan metinlerin değer iletiminde yetersiz olduğu belirtilmiştir. Çelikpazu ve Aktaş (2011) tarafından MEB 6,7, 8. sınıf ders kitapları üzerinde gerçekleştirilen çalışmada ise değer iletiminin istenen düzeyde olmadığı, 6. sınıf ders kitabında değer iletiminin daha fazla olduğu, 7 ve 8 . sınıflarda ise bu yoğunluğun azaldığı tespit edilmiştir. Fırat ve Mocan (2014) ise Türkçe ders kitaplarındaki hikâyeleri değerler iletimi açısından incelemişlerdir. Çalışmada millî değerlerin yok denecek kadar az olduğu belirtilmektedir. Pilav, Demir ve Demir (2015) 
7.sınıf Türkçe ders kitabındaki okuma metinlerini değerlerin iletimi açısından inceledikleri çalışmalarında, değerler iletiminin istenen düzeyde olmadığını tespit etmişlerdir. Pilav ve Erdoğan (2016) ortaokul ders kitabındaki bilgilendirici metinleri değer iletimi açısından inceledikleri çalışmalarında Türkçe ders kitapları oluşturulurken metinlerde millî, ahlaki ve evrensel değerlere yeterince yer verilmediği bulgusuna ulaşmışlardır. Yılar (2016) ilkokul Türkçe ders kitabı metinlerini değerler iletimi açısından incelemiştir. Çalışmasında Türkçe ders kitaplarındaki metinlerde vurgulanan değerlerin sınıflara göre benzer şekilde dağılım gösterdiğini tespit etmiştir. En fazla işlenen değerin ise sevgi olduğu görülmüştür. Çırak, Şahin, Özberk ve Eriş (2014) 5.sınıf Türkçe ders kitabındaki metinlerde ele alınan değer kategorilerinin içerisinde ele alınan 2173 cümlede vatanseverlik değerini içeren cümlelerin birinci sırada olduğunu, bunu sırasıyla denetim ve duyarlıık, bilimsel bilgi, yaratıcılık, bilimsellik, eğlence, sevgi, çalışkanlık, sorumluluk, saygı, estetik, sağlık, bağımsızlık ve dinsellik değerini içeren cümlelerin izlediğini tespit etmişlerdir. Deniz ve Karagöl (2018), 2017-2018 Eğitim-Öğretim yılında 5. ve 6. sınıflarda kullanılan Türkçe ders kitapları üzerinde bir çalışma yapmışlardır. İncelenen kitaplarda değerlerin dağılımında bir dengenin olmadığı, birkaç değere çok fazla yer verilirken bazı değerlere az yer verildiği hatta hiç yer verilmeyen değerlerin olduğu tespit edilmiştir.

Çağımızda bilgi ve teknolojide yaşanan hızlı değişmeler öğretim programlarının da güncellenmesi ve yenilenmesini gerektirmektedir. 2005 yılında yapılandırmacılık doğrultusunda hazırlanan Türkçe Dersi Öğretim Programı, 2015 ve 2017 yıllarında yenilenerek kullanıımıştır. 2018 yılında güncellenen ve yenilenen program gözden geçirilerek kullanılmaya devam edilmektedir. Türkçe ders kitapları da bu program doğrultusunda hazırlanmaktadırlar. Değerler eğitimi üzerine yapılan çalışmalara bakıldığında, bu program doğrultusunda hazırlanmış Türkçe ders kitapları üzerinde yapılmış bir çalışmaya rastlanılmamıştır. Bu nedenle, mevcut çalışmanın önemli olduğu söylenebilir.

Bu araştırmanın amacı, ortaokul Türkçe ders kitaplarındaki metinleri değerler iletimi açısından incelemek ve iletilen değerlerin 5, 6, 7 ve 8.sınıf ders kitaplarındaki dağılımını belirlemektir. Bu amaca ulaşmak için aşağıdaki alt problemler belirlenmiştir:

1. “Ortaokul 5. Sınıf Türkçe Ders Kitabı”nda (MEB Yayınları) yer alan metinlerin değerler eğitimi açısından durumu nedir?

2. “Ortaokul 6. Sınıf Türkçe Ders Kitabı”nda (Eksen Yayınları) yer alan metinlerin değerler eğitimi açısından durumu nedir?

3. “Ortaokul 7. Sınıf Türkçe Ders Kitabı”nda (Dersdestek Yayınları) yer alan metinlerin değerler eğitimi açısından durumu nedir?

4. “Ortaokul 8. Sınıf Türkçe Ders Kitabı”nda (MEB Yayınları) yer alan metinlerin değerler eğitimi açısından durumu nedir? 


\section{Yöntem}

Ortaokul Türkçe ders kitaplarındaki metinleri değerler iletimi açısından incelemeyi amaçlayan bu çalışmada, var olan bir durumu olduğu şekliyle ortaya koymayı amaçlayan tarama modeli kullanılmıştır. Tarama, geçmişte ya da hâlen var olan bir durumu var olduğu şekliyle tespit etmeyi amaçlayan araştırma modelidir (Karasar, 2017, s.109). Araştırmaya dâhil edilen Türkçe ders kitapları doküman analizi yapılarak incelenmiştir. Bu çalışmada, çalışma yapılacak kitapların veri sağlamada temel kaynak olması nedeniyle doküman analizi yöntemi benimsenmiştir. Doküman incelemesi, araştırılması hedeflenen olgu veya olgular hakkında bilgi içeren yazılı materyallerin analizini kapsar. Bu tür araştırmalarda, araştırmacı, ihtiyacı olan veriyi, gözlem veya görüşme yapmaya gerek kalmadan elde edebilir. Doküman incelemesi yapılırken dokümanlara ulaşma, orijinalliğin kontrol etme, dokümanları anlama, veriyi analiz etme, veriyi kullanma gibi aşamalar takip edilir (Yıldırım ve Şimşek, 2013, s.217-231).

\section{Evren ve Örneklem}

Çalışmanın evrenini, 5, 6, 7 ve 8.sınıf Türkçe ders kitapları oluşturmaktadır. Örnekleme yöntemi olarak da maksimum çeşitlilik örnekleme yöntemi kullanılmıştır. Bu yöntemle, araştırmanın amacıyla tutarlı olarak belirlenen farklı durumlar arasındaki ortak ya da ayrılan yönlerin, örüntülerin ortaya çıkartılması ve bu vasıtayla problemin daha geniş bir çerçevede betimlenmesidir (Büyüköztürk, Çakmak, Akgün, Karadeniz ve Demirel, 2015, s.91). Örneklem olarak Aksaray ili resmî ortaokullarda okutulmakta olan Millî Eğitim Bakanlığı yayınlarına ait 5 ve 8. sınıf Türkçe ders kitapları, Eksen yayınlarına ait 6.sınıf Türkçe ders kitabı ile Dersdestek yayınevine ait 7.sınıf Türkçe ders kitabı olmak üzere toplam dört kitap seçilmiştir.

\section{Veri Toplama Yöntemi ve Analizi}

Araştırmamızda nitel araştırma yöntemlerinden doküman analizi yöntemi kullanılmıştır. Bu yöntemde, analiz edilen dokümanın çeşidine göre sistematik süreç araştırmacı tarafından geliştirilir (Ekiz, 2015, s.78). Innceleme kapsamına alınan Türkçe ders kitabı metinleri, oluşturulan "Değerler İnceleme Formu"na göre incelenerek hangi değerlerin iletildiği tespit edilmiştir. Oluşturulan form 2018 yılı İlköğretim Sosyal Bilgiler Dersi Öğretim Programında (SBDÖP, 2018) verilen değerlerden hareketle oluşturulmuştur. Oluşturulan form, alan uzmanlarının görüşü alınarak kullanılmıştır. Verilerin çözümlenmesinde içerik çözümlemesi tekniklerinden biri olan kategorisel çözümleme kullanılmıştır. Kategorisel çözümleme, belirli bir mesajın önce birimlere bölünmesi ve ardından bu birimlerin önceden saptanmış ölçütlere göre kategoriler halinde gruplandırılmasıdır (Bilgin, 2000, s.15; Tavşancıl ve Aslan, 2001). İçerik analizi ile de elde edilen veriler tablolar halinde verilmiştir. 
Araştırmada değerler belirlenen tabloya göre kodlanırken güvenirliği sağlamak için 160 metinden rastgele her sınıf seviyesinden beş metin olmak üzere toplam 20 metin iki araştırmacı tarafından çözümlenmiş, araştırmacılar arasındaki tutarlığın güvenilir olduğu (\%92) görülmüştür. Bunun için aşağıdaki formül (Tavşancıl ve Aslan, 2001) kullanılmıştır:

Uzlaşma sayısı

Güvenilirlik =

\section{Uzlaşma + Uzlaşmama sayısı}

\section{Bulgular}

Bu bölümde Türkçe ders kitaplarında tespit edilen değerler sınıf düzeylerine göre tablolar halinde verilmiş ve değerlendirilmiştir.

Ortaokul 5. Sınıf Türkçe Ders Kitabı (MEB Yayınları) Metinlerinde Iletilen Değerler

Tablo 1. 5.sınıf Türkçe ders kitabı metinlerinde tespit edilen değerler

\begin{tabular}{|c|c|c|c|c|c|c|c|c|c|c|c|c|c|c|c|c|c|c|c|c|}
\hline 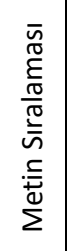 & 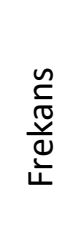 & $\frac{\frac{U}{\pi}}{\frac{\pi}{0}}$ & 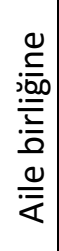 & 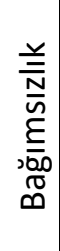 & 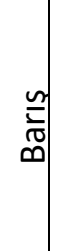 & $\begin{array}{l}\stackrel{\text { 兰 }}{\overline{\bar{n}}} \\
\stackrel{\underline{\underline{\Xi}}}{\overline{\bar{\omega}}}\end{array}$ & 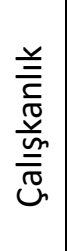 & 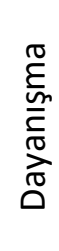 & $\frac{\text { 兰 }}{\overline{\bar{t}}}$ & 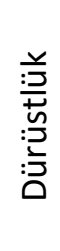 & 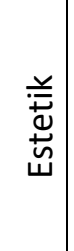 & 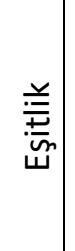 & 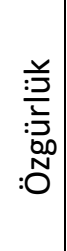 & $\begin{array}{l}\overline{50} \\
\overrightarrow{\tilde{n}} \\
\stackrel{n}{\bar{n}}\end{array}$ & $\begin{array}{l}\overline{\mathrm{b}} \\
\bar{\Downarrow} \\
\tilde{n}\end{array}$ & 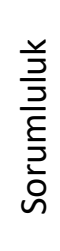 & 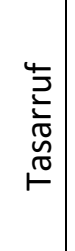 & 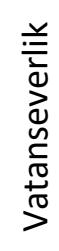 & 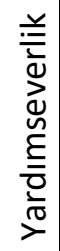 & $\begin{array}{l}\frac{\varepsilon}{\pi} \\
\frac{0}{0} \\
\frac{0}{\circ}\end{array}$ \\
\hline 1. & $f$ & & & & & & & & & $*$ & & & $*$ & & * & & & & & 3 \\
\hline 2. & $f$ & & & & & & & & $*$ & & $*$ & & $*$ & & $*$ & & & & & 4 \\
\hline 3. & $f$ & & & & & & & $*$ & $*$ & & $*$ & & & $*$ & * & $*$ & & & $*$ & 7 \\
\hline 4. & $f$ & & $*$ & & & & & & & & $*$ & & $*$ & $*$ & * & & & & & 5 \\
\hline 5. & $f$ & & & & & & & & $*$ & & & & & & $*$ & & & & $*$ & 3 \\
\hline 6. & $f$ & & & $*$ & & & $*$ & & $*$ & & & & & & & $*$ & & $*$ & $*$ & 6 \\
\hline 7. & $f$ & & & $*$ & & & $*$ & $*$ & $*$ & & & & $*$ & & $*$ & $*$ & & $*$ & $*$ & 9 \\
\hline 8. & $f$ & & & $*$ & $*$ & & & $*$ & $*$ & & & & $*$ & & $*$ & $*$ & & $*$ & & 8 \\
\hline 9. & $f$ & $*$ & $*$ & $*$ & $*$ & $*$ & $*$ & $*$ & $*$ & $*$ & & $*$ & $*$ & $*$ & $*$ & $*$ & & $*$ & $*$ & 16 \\
\hline 10. & $f$ & & $*$ & $*$ & & & $*$ & $*$ & $*$ & & $*$ & & $*$ & & $*$ & $*$ & & $*$ & $*$ & 11 \\
\hline 11. & $f$ & $*$ & & & & & $*$ & $*$ & $*$ & & & & $*$ & & * & $*$ & & & $*$ & 8 \\
\hline 12. & $f$ & & $*$ & & $*$ & & & & $*$ & & $*$ & & & & $*$ & $*$ & & & & 6 \\
\hline 13. & $f$ & & & & & & $*$ & & & $*$ & & & & $*$ & $*$ & $*$ & & & & 5 \\
\hline 14. & $f$ & & & & & & & * & $*$ & & & & & $*$ & & & & & $*$ & 4 \\
\hline 15. & $f$ & & & & & & $*$ & & $*$ & & & & & $*$ & $*$ & $*$ & & & & 5 \\
\hline 16. & $f$ & & & & & $*$ & $*$ & $*$ & & & & & & & & $*$ & & & $*$ & 5 \\
\hline 17. & $f$ & & & & & $*$ & $*$ & & & & & & & & & & $*$ & & & 3 \\
\hline 18. & $f$ & & & & & $*$ & $*$ & $*$ & $*$ & & & & & & $*$ & $*$ & & $*$ & $*$ & 8 \\
\hline 19. & $f$ & & & & & $*$ & $*$ & $*$ & $*$ & $*$ & $*$ & & & $*$ & $*$ & $*$ & $*$ & $*$ & $*$ & 12 \\
\hline 20. & $f$ & & & & $*$ & $*$ & & & & & & & & & & & & & & 2 \\
\hline 21. & $f$ & & & & & & & $*$ & $*$ & & $*$ & & & & $*$ & & & $*$ & $*$ & 6 \\
\hline 22. & $f$ & & & $*$ & & & & & $*$ & $*$ & & & $*$ & $*$ & $*$ & & & $*$ & & 7 \\
\hline 23. & $f$ & & & & & $*$ & & & & & $*$ & & & & & & & & & 2 \\
\hline 24. & $f$ & & & & & & & $*$ & & & & & & $*$ & $*$ & & & $*$ & $*$ & 5 \\
\hline 25. & $f$ & & & & & & $*$ & $*$ & & & $*$ & & & $*$ & & $*$ & & & & 5 \\
\hline 26. & $f$ & & & & & & $*$ & & $*$ & $*$ & $*$ & & & & $*$ & $*$ & & & & 6 \\
\hline
\end{tabular}




\begin{tabular}{|l|l|l|l|l|l|l|l|l|l|l|l|l|l|l|l|l|l|l|l|l|}
\hline 27. & $\mathrm{f}$ & & & & & $*$ & & & & & $*$ & $*$ & & & $*$ & & & & & 4 \\
\hline 28. & $\mathrm{f}$ & & & & & $*$ & $*$ & & & & $*$ & & $*$ & & $*$ & $*$ & & & & 6 \\
\hline 29. & $\mathrm{f}$ & $*$ & $*$ & & & $*$ & $*$ & $*$ & $*$ & & & $*$ & & $*$ & $*$ & $*$ & & $*$ & $*$ & 12 \\
\hline 30. & $\mathrm{f}$ & & & & & & & & & $*$ & $*$ & & & $*$ & & & & & $*$ & 4 \\
\hline 31. & $\mathrm{f}$ & $*$ & $*$ & $*$ & $*$ & $*$ & & $*$ & & & & & & $*$ & $*$ & & & $*$ & & 9 \\
\hline 32. & $\mathrm{f}$ & & & & & $*$ & $*$ & & $*$ & & & & & $*$ & & $*$ & & & & 5 \\
\hline 33. & $\mathrm{f}$ & & & & & & & & & & $*$ & & & $*$ & & & & $*$ & & 3 \\
\hline 34. & $\mathrm{f}$ & & & & & $*$ & & & $*$ & $*$ & & & & & & & & & $*$ & 4 \\
\hline 35. & $\mathrm{f}$ & & $*$ & & & & & $*$ & $*$ & & & & & $*$ & $*$ & & & & $*$ & 6 \\
\hline 36. & $\mathrm{f}$ & & & & & & & & $*$ & & & & & $*$ & & & & & & 2 \\
\hline 37. & $\mathrm{f}$ & & & & & $*$ & & & $*$ & & & & & $*$ & $*$ & & & & $*$ & 5 \\
\hline 38. & $\mathrm{f}$ & & & & & $*$ & & & & & $*$ & & & $*$ & & & & & & 3 \\
\hline 39. & $\mathrm{f}$ & & & & & & & & & & $*$ & & & $*$ & & & & & $*$ & 3 \\
\hline 40. & $\mathrm{f}$ & & & & & $*$ & & & & & & & & & & & & & & 1 \\
\hline T & $\mathrm{f}$ & 4 & 7 & 7 & 5 & 16 & 16 & 16 & 23 & 8 & 16 & 3 & 10 & 20 & 25 & 18 & 2 & 13 & 19 & $\mathbf{2 2 8}$ \\
\hline
\end{tabular}

Tablo 1 incelendiğinde, 5.sınıf Türkçe ders kitabı metinlerinde en fazla sevgi (f: 25), saygı (f: 20), yardımlaşma (f: 19), sorumluluk (f: 18) değerlerine yer verildiği görülmektedir. Tasarruf (f: 2), eşitlik (f: 3), adalet (f: 4) gibi değerlerine ise çok az verilmesi bir eksiklik olarak görülmektedir. Metinler açısından bakıldığı zaman, en fazla değere sahip olan metinlerin Dersimiz Atatürk (f: 16), Küçük Şeylerin HikâyesiKütüphane (f: 12), Sanki Caminin Bakım Kılavuzu (f:12), Küçük Ağa (f: 11) olduğu tespit edilmiştir. "Küçük Ağa" metni hariç diğer metinler dinleme-izleme metni olarak belirlenmiştir. En az değere sahip olan metinlerin ise Eyvah Ormanda Kayboldum (f: 1), Tamburi Cemil Bey Enstrümanları Anlatıyor (f: 2), Jules Verne'den Geleceğe Dair (f: 2) olduğu tespit edilmiştir.

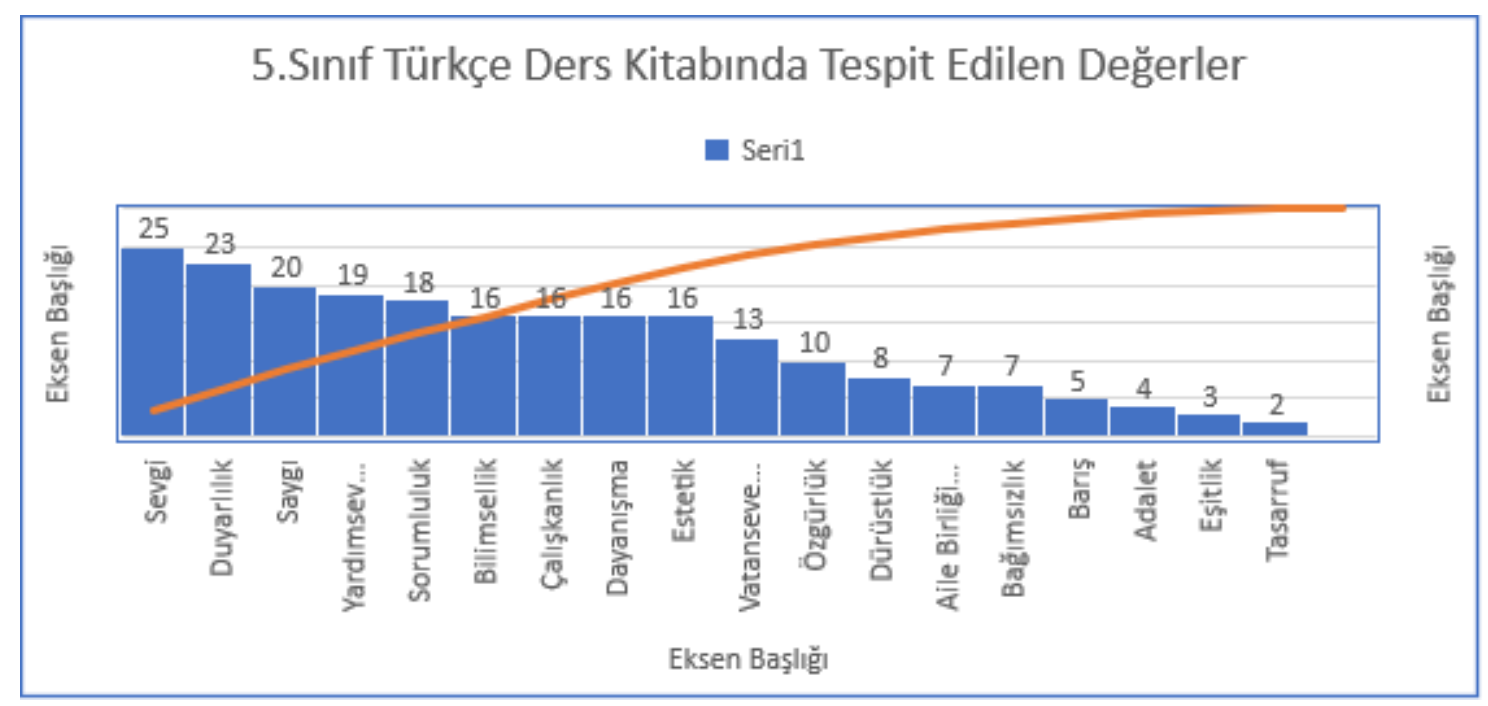

Şekil 1. 5.Sınıf Türkçe Ders Kitabı Metinlerinde Tespit Edilen Değerler 
Ortaokul 6. Sınıf Türkçe Ders Kitabı (Eksen Yayınları) Metinlerinde Iletilen Değerler

Tablo 2. 6.sınıf Türkçe ders kitabı metinlerinde tespit edilen değerler

\begin{tabular}{|c|c|c|c|c|c|c|c|c|c|c|c|c|c|c|c|c|c|c|c|c|}
\hline 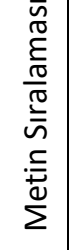 & 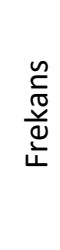 & $\frac{\frac{\pi}{0}}{\frac{\pi}{0}}$ & 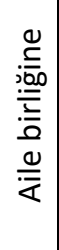 & 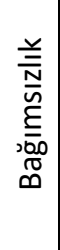 & 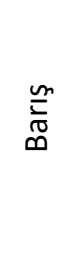 & 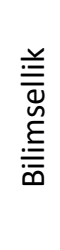 & 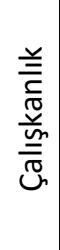 & 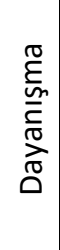 & 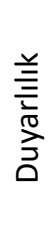 & 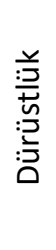 & 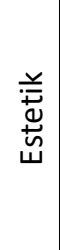 & 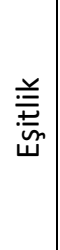 & 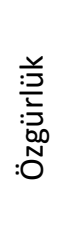 & 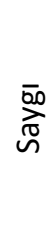 & $\begin{array}{l}\overline{60} \\
\bar{\varpi} \\
\sim\end{array}$ & 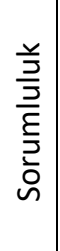 & 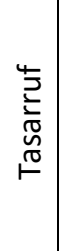 & 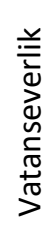 & 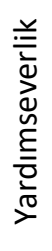 & $\begin{array}{l}\varepsilon \\
\frac{E}{\pi} \\
\frac{0}{0} \\
\text { - }\end{array}$ \\
\hline 1. & $f$ & & & $*$ & & & $*$ & & $*$ & & & & $*$ & $*$ & $*$ & $*$ & & $*$ & $*$ & 9 \\
\hline 2. & $f$ & $*$ & & & & $*$ & & & & $*$ & & $*$ & & & & $*$ & & & & 5 \\
\hline 3. & $f$ & & $*$ & & & & $*$ & $*$ & $*$ & $*$ & & & & $*$ & $*$ & $*$ & & & $*$ & 9 \\
\hline 4. & $f$ & & & & & & & & $*$ & & & & & & & & & & $*$ & 2 \\
\hline 5. & $f$ & & & & & & & $*$ & & & & & & & $*$ & & & & $*$ & 3 \\
\hline 6. & $f$ & & & & & & & $*$ & . & & & & & $*$ & $*$ & & & $*$ & & 4 \\
\hline 7. & $f$ & & & & & & & & $*$ & & $*$ & & & & $*$ & & & $*$ & & 4 \\
\hline 8. & $f$ & & & & & & & $*$ & $*$ & & & & & & $*$ & & & & $*$ & 4 \\
\hline 9. & $f$ & & & $*$ & & & & & & & $*$ & & $*$ & & $*$ & & & $*$ & & 5 \\
\hline 10. & $f$ & & & & & . & & & $*$ & & & & & . & $*$ & & & & & 2 \\
\hline 11. & $f$ & & & & & $*$ & $*$ & & $*$ & & & & & $*$ & * & $*$ & & $*$ & $*$ & 8 \\
\hline 12. & $f$ & & & & & $*$ & $*$ & & $*$ & & & & & & & & & & & 3 \\
\hline 13. & $f$ & & & $*$ & & & & $*$ & & & $*$ & & $*$ & & & & & $*$ & & 5 \\
\hline 14. & $f$ & & & & $*$ & & & $*$ & & & $*$ & & & & & & & & & 3 \\
\hline 15. & $f$ & & & $*$ & & & & $*$ & $*$ & & & & $*$ & & & $*$ & & $*$ & & 6 \\
\hline 16. & $f$ & $*$ & & & & & & & & $*$ & & & & & & & & & & 2 \\
\hline 17. & $f$ & & $*$ & & & & & & & & & & $*$ & & $*$ & $*$ & & & & 4 \\
\hline 18. & $f$ & & & & & & & & & & & & & & $*$ & $*$ & & & & 2 \\
\hline 19. & $f$ & & & & & & & & $*$ & $*$ & & & $*$ & & & & & & & 3 \\
\hline 20. & $f$ & & & & & & & & $*$ & & $*$ & & & & $*$ & & & & & 3 \\
\hline 21. & $f$ & & & & $*$ & & & & $*$ & & $*$ & & & & $*$ & & & & & 4 \\
\hline 22. & $f$ & & & & & & & & $*$ & & & & & & & $*$ & $*$ & & & 3 \\
\hline 23. & $f$ & & $*$ & & & & & $*$ & $*$ & & & & & & $*$ & & & & & 4 \\
\hline 24. & $f$ & & & & & & & $*$ & & & & & & & $*$ & & $*$ & $*$ & & 4 \\
\hline 25. & $f$ & & & & & & & & $*$ & & & & & $*$ & & $*$ & & & & 3 \\
\hline 26. & $f$ & & & & & & & & $*$ & & & & & $*$ & $*$ & & & & & 3 \\
\hline 27. & $f$ & & $*$ & & & & & $*$ & $*$ & & & & & & $*$ & & & & & 4 \\
\hline 28 & $f$ & & $*$ & & & & & & $*$ & & & & & $*$ & $*$ & $*$ & & & & 5 \\
\hline 29. & $f$ & & & & & $*$ & & & & $*$ & & & & & & & & & & 2 \\
\hline 30. & $f$ & & $*$ & & & $*$ & & & & & & & & & & & $*$ & & & 3 \\
\hline 31. & $f$ & & & & & $*$ & & & $*$ & & & & & & $*$ & $*$ & & & & 4 \\
\hline 32. & $f$ & & & & & $*$ & & & $*$ & & & & & & & $*$ & & & & 3 \\
\hline 33. & $f$ & & & & & & & & $*$ & & & & & & $*$ & $*$ & & & & 3 \\
\hline 34. & $f$ & & & & & & & $*$ & $*$ & & & & & & & $*$ & & & $*$ & 4 \\
\hline 35. & $f$ & & & & & & & & & & $*$ & & & & & & & & & 1 \\
\hline 36. & $f$ & & & & & & & & $*$ & & $*$ & & & & $*$ & & & & & 3 \\
\hline 37. & $f$ & & $*$ & & & $*$ & $*$ & $*$ & & & & & & & $*$ & $*$ & & & & 6 \\
\hline 38. & $f$ & & & & & $*$ & $*$ & & & & & & & & & & & & & 2 \\
\hline 39. & $f$ & & & & & $*$ & & & & & & & & & & & & $*$ & $*$ & 3 \\
\hline 40. & $f$ & & & & & $*$ & $*$ & & & & & & & & $*$ & & & $*$ & & 4 \\
\hline
\end{tabular}


Türkçe Ders Kitaplarındaki Metinlerin İlettiği Değerler Açısından İncelenmesi

\begin{tabular}{|l|l|l|l|l|l|l|l|l|l|l|l|l|l|l|l|l|l|l|l|l|}
\hline $\mathbf{T}$ & $\mathrm{F}$ & 2 & 7 & 4 & 2 & 11 & 7 & 12 & 23 & 5 & 8 & 1 & 6 & 7 & 23 & 15 & 3 & 10 & 8 & 154 \\
\hline
\end{tabular}

Tablo 2 incelendiğinde, ortaokul 6. sınıf Türkçe ders kitabı metinlerde sevgi (f: 23), duyarlılık (f: 23), sorumluluk (f: 15), dayanışma (f: 12), bilimsellik (f: 11) , vatanseverlik (f: 10) değerlerine daha fazla yer verildiği görülmektedir. Eşitlik (f: 1 ), adalet (f: 2 ), barış (f: 2 ), tasarruf (f: 3 ) değerlerine ise en az sayıda yer verildiği bulgusuna ulaşılmıştır. Ders kitabındaki metinler ilettiği değerler açısından incelendiğinde de Forsa (f: 9), Ceylana Yardım Edenler (f: 9), Atatürk Orman Çiftliği (f: 8) metinlerinde daha fazla; Gün Doğuyor (f: 1), Adsız Çeşme (f: 2), Önce İğneyi Kendine Batır, Sonra Çuvaldızı Ele (f: 2), Nasrettin Hoca Fıkraları (f: 2), Bilmece (f: 2), Bilgilenirken Medya (f: 2), Newton'un Elması (f: 2) metinlerinde ise daha az değer bulgusuna rastlanılmıştır. Metinler arasında, iletilen değerlerin frekansı yönüyle bir dengesizlik söz konusudur. Metin seçiminde farklı değerlere sahip olan metinler ders kitaplarına seçilmelidir.

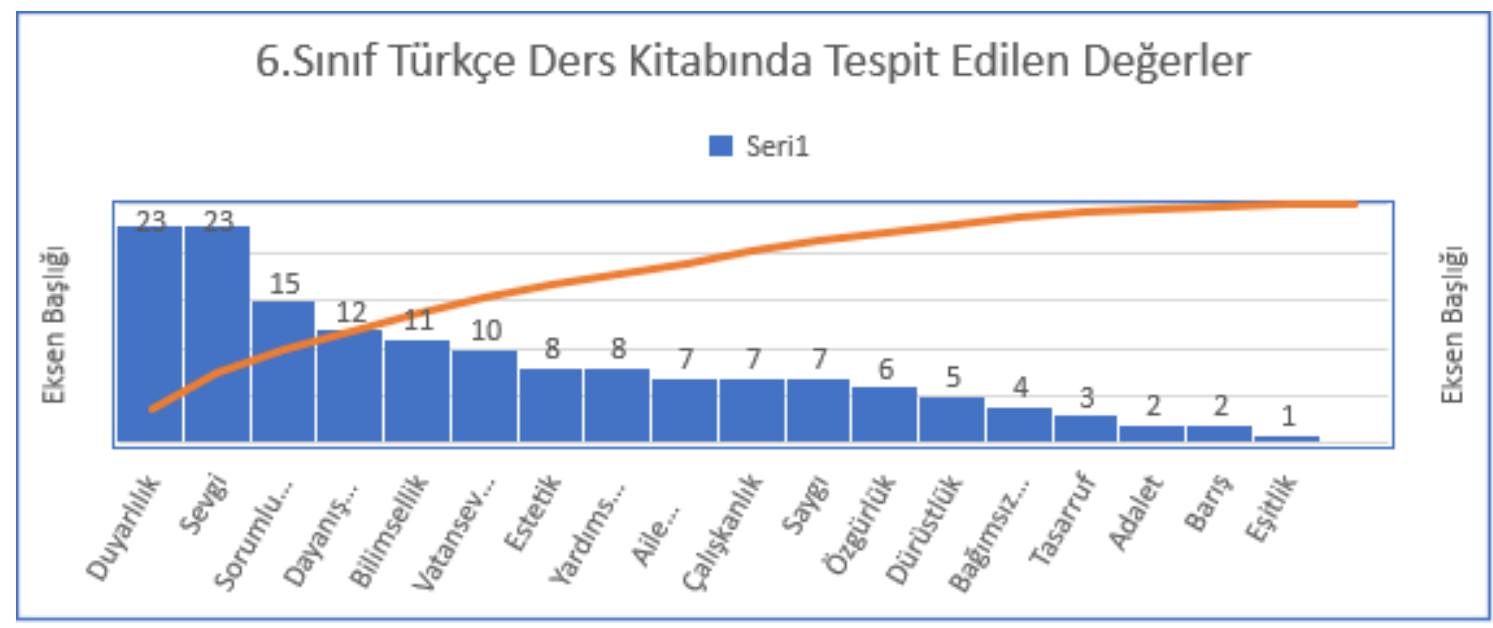

Şekil 2. 6.Sınıf Türkçe Ders Kitabı Metinlerinde Tespit Edilen Değerler

Ortaokul 7. Sınıf Türkçe Ders Kitabı (Dersdestek Yayınları) Metinlerinde Iletilen Değerler

Tablo 3. 7.sınıf Türkçe ders kitabı metinlerinde tespit edilen değerler

\begin{tabular}{|c|c|c|c|c|c|c|c|c|c|c|c|c|c|c|c|c|c|c|c|c|}
\hline 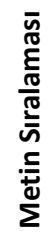 & 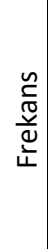 & $\frac{\frac{d}{\frac{\pi}{\pi}}}{\frac{\pi}{2}}$ & 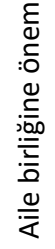 & 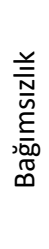 & $\begin{array}{l}\frac{m}{2} \\
\stackrel{D}{D} \\
\infty\end{array}$ & $\begin{array}{l}\text { 兰 } \\
\overline{\bar{\omega}} \\
\underline{\underline{\underline{\underline{\omega}}}}\end{array}$ & 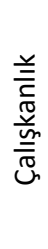 & 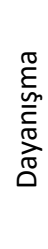 & 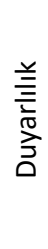 & 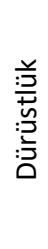 & 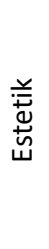 & 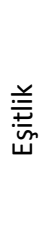 & 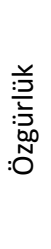 & 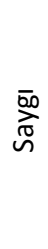 & 品 & 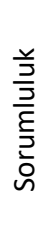 & 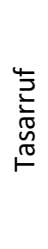 & 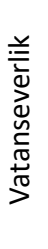 & 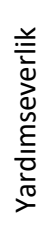 & $\frac{\frac{\varepsilon}{\pi}}{\frac{\pi}{0}}$ \\
\hline 1. & $f$ & & $*$ & & $*$ & & & $*$ & $*$ & $*$ & & & & $*$ & $*$ & & & & $*$ & 8 \\
\hline 2. & $f$ & & & & & & & $*$ & $*$ & & & & & $*$ & $*$ & & & & $*$ & 5 \\
\hline 3. & $f$ & & $*$ & & & & & $*$ & $*$ & $*$ & & & & $*$ & $*$ & $*$ & & & $*$ & 8 \\
\hline 4. & $f$ & & & & $*$ & $*$ & $*$ & & & & & $*$ & $*$ & $*$ & & & & & & 6 \\
\hline 5. & $f$ & & & & & & & & $*$ & $*$ & & & & & & $*$ & & & $*$ & 4 \\
\hline 6. & $f$ & & & & & $*$ & & & & & & & & & & & & & & 1 \\
\hline
\end{tabular}




\begin{tabular}{|c|c|c|c|c|c|c|c|c|c|c|c|c|c|c|c|c|c|c|c|c|}
\hline 7. & $f$ & & & & & & & & & & $*$ & & $*$ & & $*$ & & & & $*$ & 4 \\
\hline 8. & $f$ & & & & & $*$ & $*$ & $*$ & $*$ & & $*$ & & & & $*$ & & & $*$ & & 7 \\
\hline 9. & $f$ & & & & & $*$ & & & $*$ & & & & & & $*$ & $*$ & & & & 4 \\
\hline 10. & $f$ & & $*$ & & & & & & & & & & & & $*$ & & & & & 2 \\
\hline 11. & $f$ & & & $*$ & & & & & & & $*$ & & & $*$ & $*$ & & & $*$ & & 5 \\
\hline 12. & $f$ & & & & $*$ & & & $*$ & $*$ & $*$ & & & & $*$ & $*$ & $*$ & & & $*$ & 8 \\
\hline 13. & $f$ & $*$ & & $*$ & & & & $*$ & & & & $*$ & $*$ & $*$ & $*$ & $*$ & & $*$ & & 9 \\
\hline 14. & $f$ & & & & & & & & & & & & & & $*$ & $*$ & & & & 2 \\
\hline 15. & $f$ & * & & & & & $*$ & & * & & & & & & $*$ & & & & & 4 \\
\hline 16. & $f$ & & * & $*$ & & & $*$ & $*$ & * & & $*$ & & $*$ & & $*$ & $*$ & & $*$ & & 10 \\
\hline 17. & $f$ & & & $*$ & & & $*$ & $*$ & $*$ & & & & $*$ & & $*$ & $*$ & & $*$ & $*$ & 9 \\
\hline 18. & $f$ & & & & $*$ & $*$ & $*$ & $*$ & $*$ & & $*$ & & & & $*$ & & & $*$ & $*$ & 9 \\
\hline 19. & $f$ & & & $*$ & & & & $*$ & $*$ & & & & $*$ & $*$ & $*$ & $*$ & & $*$ & & 8 \\
\hline 20. & $f$ & & $*$ & $*$ & & & $*$ & $*$ & $*$ & & & & $*$ & $*$ & $*$ & & & $*$ & $*$ & 10 \\
\hline 21. & $f$ & $*$ & & & & & & $*$ & & $*$ & & $*$ & & $*$ & & & & & $*$ & 6 \\
\hline 22. & $f$ & $*$ & & & & & & & & & & & & & & & & & & 1 \\
\hline 23. & $f$ & & & & & & & & $*$ & $*$ & & & & $*$ & & $*$ & & & & 4 \\
\hline 24. & $f$ & & & & & & $*$ & & & & & & & & $*$ & * & & & & 3 \\
\hline 25. & $f$ & & & & & & $*$ & & * & & * & & & & & $*$ & & & & 4 \\
\hline 26. & $f$ & & & & $*$ & & $*$ & & $*$ & & & & & & $*$ & $*$ & & & & 5 \\
\hline 27. & $f$ & & & & & & & $*$ & 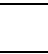 & & & & $*$ & $*$ & $*$ & $*$ & & & $*$ & 6 \\
\hline 28. & $f$ & & & & & $*$ & & & $*$ & & & & & & & $*$ & & & & 3 \\
\hline 29. & $f$ & & & & & & $*$ & & $*$ & & & $*$ & & & & & & & $*$ & 4 \\
\hline 30. & $f$ & & & & & $*$ & & & & & & & & & & $*$ & & & & 2 \\
\hline 31. & $f$ & & & & & & $*$ & & $*$ & & $*$ & & & & $*$ & & & & & 4 \\
\hline 32. & $f$ & & & & & $*$ & $*$ & & $*$ & & $*$ & & & & & & & & & 4 \\
\hline 33. & $f$ & & & & & $*$ & & & $*$ & & $*$ & & $*$ & $*$ & $*$ & $*$ & & & & 7 \\
\hline 34. & $f$ & & & & & & & & $*$ & & * & & & & & & & & & 2 \\
\hline 35. & $f$ & & & & & & $*$ & & $*$ & & & & & $*$ & & & & & & 3 \\
\hline 36. & $f$ & & & & & $*$ & $*$ & $*$ & $*$ & & $*$ & & & & & & & & & 5 \\
\hline 37. & $f$ & & & & & & & & $*$ & & & & & & $*$ & & & & & 2 \\
\hline 38. & $f$ & & & & & $*$ & & & & & & & & & & & $*$ & & & 2 \\
\hline 39. & $f$ & & & & & $*$ & $*$ & $*$ & & & & & & $*$ & & $*$ & & & & 5 \\
\hline 40. & $f$ & & & & & $*$ & $*$ & & & & $*$ & & & & $*$ & & & & & 4 \\
\hline $\mathbf{T}$ & $\mathrm{F}$ & 4 & 5 & 6 & 5 & 13 & 17 & 15 & 25 & 6 & 12 & 4 & 9 & 15 & 24 & 18 & 1 & 8 & 12 & 199 \\
\hline
\end{tabular}

Tablo 3 incelendiğinde, ortaokul 7.sınıf Türkçe ders kitabında metinlerin 25'inde duyarlılık, 24'ünde sevgi, 18'inde sorumluluk, 17'sinde çalışkanlık, 13'ünde bilimsellik ve 12'sinde yardımlaşma değerine yer verildiği görülmektedir. En az yer verilen değerin ise tasarruf ( $f: 1$ ) olduğu bulgusuna ulaşılmıştır. Adalet (f: 4), eşitlik (f: 4), aile birliğine önem verme (f: 5) ve barış (f: 5) değerlerine de az yer verildiği tespit edilmiştir.16.sırada yer alan "istanbul Liseli Küçük Hasan” metninde aile birliğine önem verme, bağımsızlık, çalışkanlık, dayanışma, duyarlılık, estetik, özgürlük, sevgi, sorumluluk, vatanseverlik olmak üzere toplam 10 değer bulgusuna ulaşılmıştır. 20.sırada yer alan "Samsun Yolculuğuna Hazırlık" (f: 10) metninde de aile birliğine önem verme, bağımsızlık, çalışkanlık, dayanışma, duyarlıık, özgürlük, saygı, sevgi, vatanseverlik ve yardımlaşma değerleri yer almaktadır. 22.sırada yer 
alan "Yemeğin Buharını Yiyen, Ücretini Para Sesi Olarak Öder" metninde adalet, 6.sırada bulunan "Yer Çekimsiz yaşam" metninde ise bilimsellik olmak üzere birer değer bulgusuna ulaşılmıştır. Tasarruf, adalet, eşitlik, aile birliğine önem verme gibi bazı değerlerin az yer alması büyük bir eksikliktir. Ders kitabına metin seçiminde göz önünde bulundurulması gereken hususlardan biri de metinlerde değer çeşitliliğine özen gösterilmesidir.

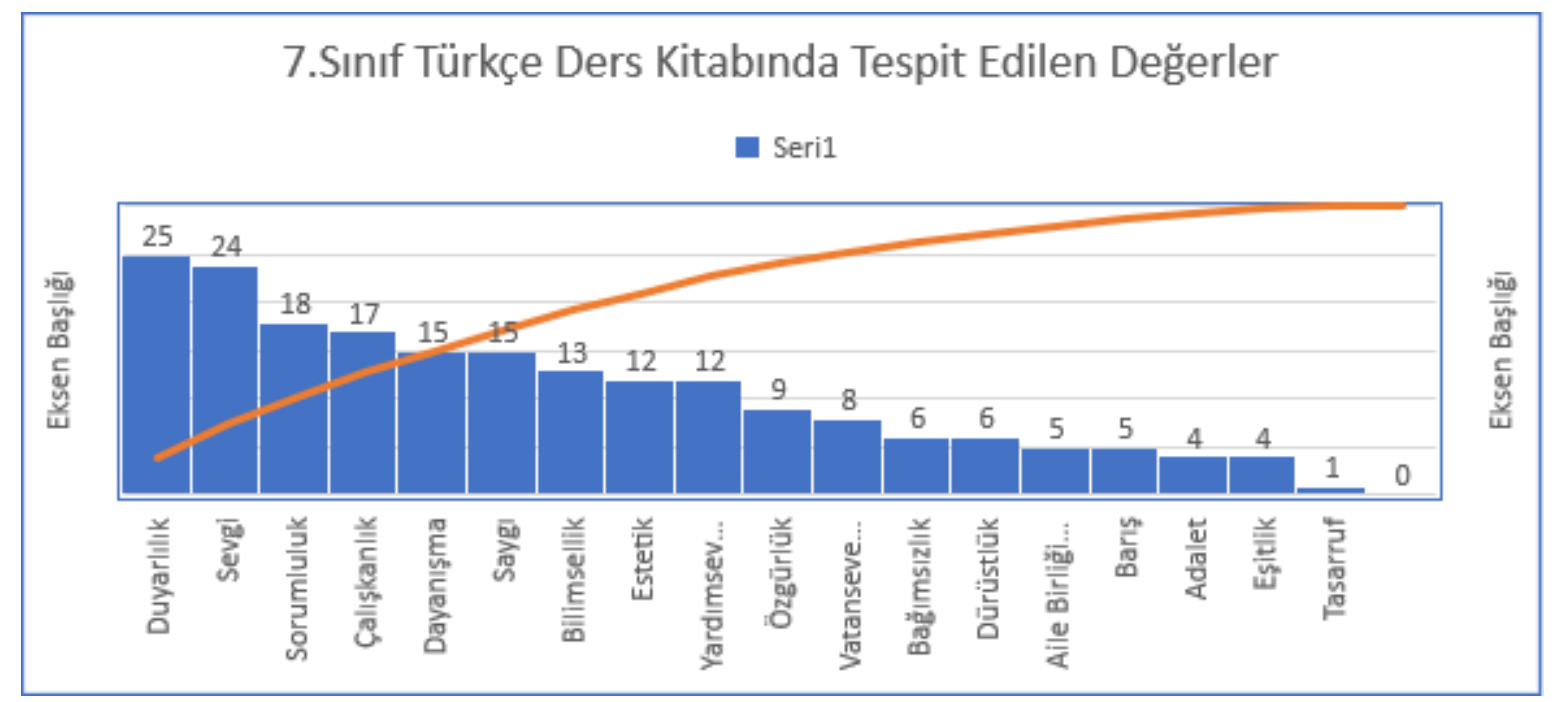

Şekil 3. 7.Sınıf Türkçe Ders Kitabı Metinlerinde Tespit Edilen Değerler

Ortaokul 8. Sınıf Türkçe Ders Kitabı (MEB Yayınları) Metinlerinde Iletilen Değerler

Tablo 4. 8.sınıf Türkçe ders kitabı metinlerinde tespit edilen değerler

\begin{tabular}{|c|c|c|c|c|c|c|c|c|c|c|c|c|c|c|c|c|c|c|c|c|}
\hline 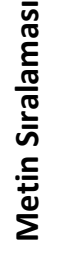 & $\begin{array}{l}\frac{n}{0} \\
\frac{\tilde{v}}{\omega} \\
\frac{\omega}{4}\end{array}$ & $\frac{\frac{\mathbb{Q}}{\pi}}{\frac{\pi}{Q}}$ & 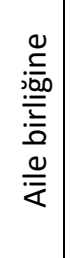 & 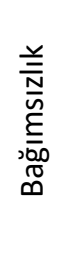 & $\begin{array}{l}\frac{m}{ \pm} \\
\frac{m}{D} \\
\infty\end{array}$ & 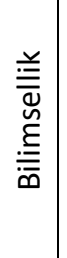 & 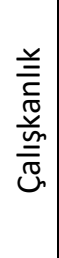 & 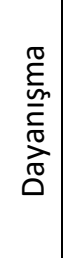 & 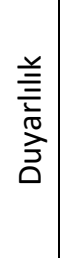 & 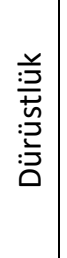 & 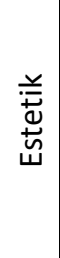 & 美 & 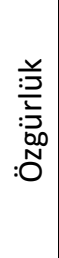 & $\begin{array}{l}\overline{50} \\
\underset{\pi}{\tilde{N}}\end{array}$ & 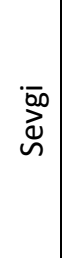 & $\begin{array}{l}\frac{\text { J }}{\frac{J}{3}} \\
\frac{\xi}{3} \\
\frac{0}{n}\end{array}$ & 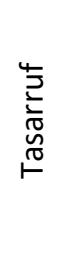 & 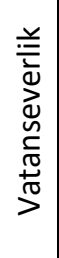 & 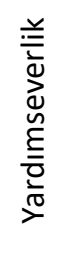 & $\begin{array}{l}\varepsilon \\
\frac{\varepsilon}{\pi} \\
\frac{0}{0} \\
\circ\end{array}$ \\
\hline 1. & $f$ & & & & & & * & & $*$ & & & & & $*$ & $*$ & & & & $*$ & 5 \\
\hline 2. & $f$ & & & & & & $*$ & & & & $*$ & & $*$ & & & & & & & 3 \\
\hline 3. & $f$ & & $*$ & & & & & & & & & & & $*$ & $*$ & & & & & 3 \\
\hline 4. & $f$ & & & & & & $*$ & & & & & & & & $*$ & & & & & 2 \\
\hline 5. & $f$ & & & & & & $*$ & & & & & & $*$ & & $*$ & $*$ & & & & 4 \\
\hline 6. & $f$ & & & $*$ & & & & & $*$ & & & & & & $*$ & $*$ & & $*$ & & 5 \\
\hline 7. & $f$ & & & $*$ & & & & & $*$ & & & & & & & $*$ & & $*$ & & 4 \\
\hline 8. & $f$ & & & $*$ & & & & & & & & & & $*$ & & $*$ & & $*$ & & 4 \\
\hline 9. & $f$ & & & $*$ & & & & $*$ & $*$ & & & & & & $*$ & & & $*$ & & 5 \\
\hline 10. & $f$ & & & & & & $*$ & & & & & & & $*$ & $*$ & & & & & 3 \\
\hline 11. & $f$ & & & & & & * & $*$ & $*$ & & & & & $*$ & $*$ & $*$ & & & $*$ & 7 \\
\hline 12. & $f$ & & & & & & & & & & $*$ & & & & $*$ & & & & & 2 \\
\hline 13. & $f$ & & & & & & & $*$ & & & & & & & $*$ & & & $*$ & & 3 \\
\hline 14. & $f$ & & & & & & & $*$ & $*$ & & & & & & $*$ & $*$ & & & $*$ & 5 \\
\hline 15. & $f$ & $*$ & & & & & $*$ & & $*$ & $*$ & & & & & $*$ & $*$ & & & & 6 \\
\hline 16. & $f$ & & & & & & & & & & $*$ & & & & $*$ & & & $*$ & & 3 \\
\hline
\end{tabular}




\begin{tabular}{|c|c|c|c|c|c|c|c|c|c|c|c|c|c|c|c|c|c|c|c|c|}
\hline 17. & $f$ & & & & & & $*$ & & & & $*$ & & & & & $*$ & & $*$ & & 4 \\
\hline 18. & $f$ & & & & & & & & $*$ & & $*$ & & & & $*$ & & & $*$ & & 4 \\
\hline 19. & $f$ & & & & & & $*$ & & $*$ & & $*$ & & & & & & & & $*$ & 4 \\
\hline 20. & $f$ & & $*$ & & & & & $*$ & $*$ & & $*$ & & $*$ & $*$ & $*$ & $*$ & & & $*$ & 9 \\
\hline 21. & $f$ & & & & & & & & & & $*$ & & & & $*$ & & & $*$ & & 3 \\
\hline 22. & $f$ & & & & & & & & & & & $*$ & & & & & & & & 1 \\
\hline 23. & $f$ & & & * & $*$ & & & $*$ & & & & & $*$ & & & & & $*$ & & 5 \\
\hline 24. & $f$ & $*$ & & & & & $*$ & $*$ & $*$ & & & & & & & & & & $*$ & 5 \\
\hline 25. & $f$ & & $*$ & & & & & & $*$ & & & & & & $*$ & & & & & 3 \\
\hline 26. & $f$ & & $*$ & & & & & & $*$ & & $*$ & & & $*$ & $*$ & & & & & 5 \\
\hline 27. & $f$ & & & & & & $*$ & & & & & & & & $*$ & & & & & 2 \\
\hline 28. & $f$ & & $*$ & & & & & $*$ & & & & & & $*$ & $*$ & & & & $*$ & 5 \\
\hline 29. & $f$ & & $*$ & & & & & $*$ & & & & & & & & & & & $*$ & 3 \\
\hline 30. & $f$ & & & & & & & & & & & & & & $*$ & & & $*$ & & 2 \\
\hline 31. & $f$ & & & & & $*$ & $*$ & $*$ & $*$ & & $*$ & & & $*$ & $*$ & $*$ & & & & 8 \\
\hline 32. & $f$ & & & & & & & & $*$ & & $*$ & & & $*$ & $*$ & & & & & 4 \\
\hline 33. & $f$ & & $*$ & & & & $*$ & $*$ & $*$ & & $*$ & & & & $*$ & $*$ & $*$ & & $*$ & 9 \\
\hline 34. & $f$ & & & & & $*$ & & $*$ & $*$ & & & $*$ & & $*$ & $*$ & $*$ & & & $*$ & 8 \\
\hline 35. & $f$ & & & & & & $*$ & & & & & & & & $*$ & & & & $*$ & 3 \\
\hline 36. & $f$ & & & & & $*$ & $*$ & $*$ & & & & & & & & & & & & 3 \\
\hline 37. & $f$ & & & * & & & $*$ & $*$ & $*$ & & & & $*$ & & & & & $*$ & & 6 \\
\hline 38. & $f$ & & & & & & & & & & & & $*$ & & & & & & & 1 \\
\hline 39. & $f$ & & $*$ & & & & & $*$ & $*$ & & & & $*$ & & $*$ & $*$ & & & $*$ & 7 \\
\hline 40. & $f$ & $*$ & & & & & & & & & & & & & $*$ & & & & $*$ & 3 \\
\hline$T$ & $\mathrm{~F}$ & 3 & 8 & 6 & 1 & 3 & 15 & 15 & 19 & 1 & 12 & 2 & 7 & 11 & 28 & 13 & 1 & 12 & 13 & 170 \\
\hline
\end{tabular}

Tablo 4 incelendiğinde, ortaokul 8.sınıf Türkçe ders kitabında en fazla sevgi (f: 27), duyarlıık (f: 19), çalışkanlık (f: 15), dayanışma (f: 15), estetik (f: 12), sorumluluk (f: 13), vatanseverlik (f: 12) ve yardımseverlik (f: 13) olduğu bulgusuna ulaşılmıştır. Barış, tasarruf, dürüstlük değerlerine birer metinde yer verildiği görülmektedir. Taşıdığı değerler yönüyle 20’nci sırada yer alan “Bir Baba/ Bir Zihniyet" (f: 9) ile 33'üncü sırada yer alan "Emine Teyze'nin Çilek Reçeli" (f: 9) en fazla değere sahip olan metinlerdir. "Burada Dur" ve "Özgürlük" metinlerinde ise yalnızca birer değer bulgusuna ulaşılımıştır.

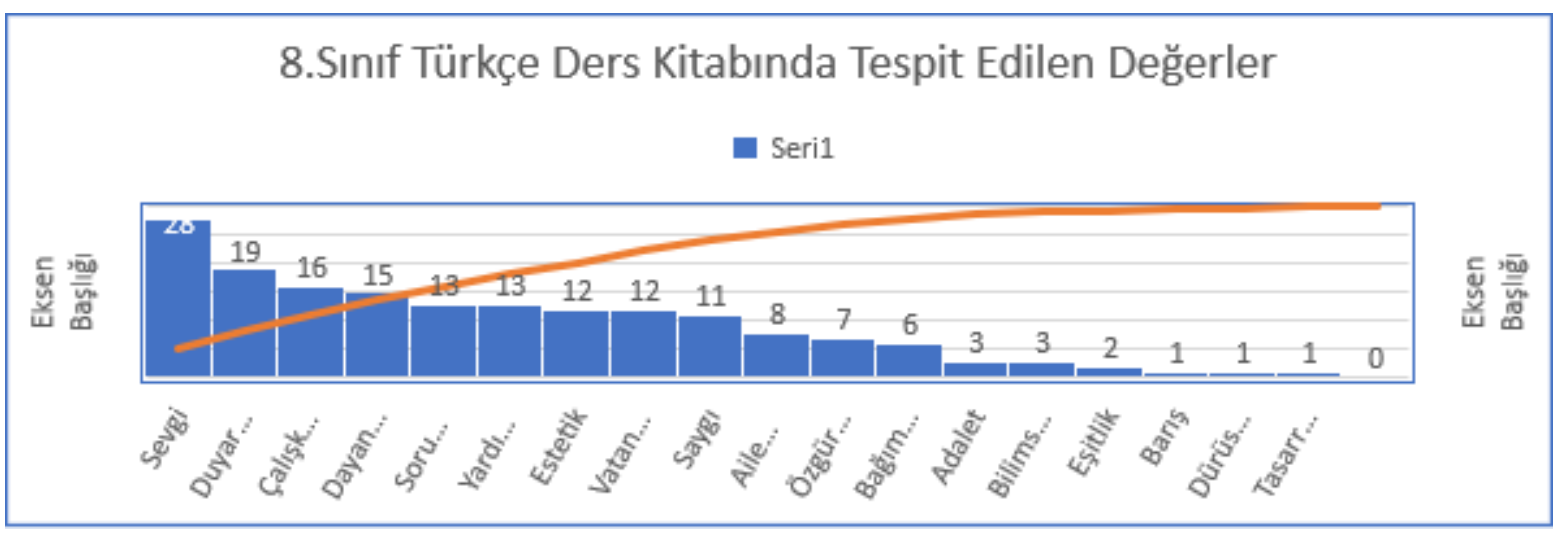

Şekil 4. 8.Sınıf Türkçe Ders Kitabı Metinlerinde Tespit Edilen Değerler 


\begin{tabular}{|c|c|c|c|c|c|c|c|c|c|c|c|c|c|c|c|c|c|c|c|c|}
\hline 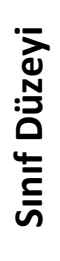 & 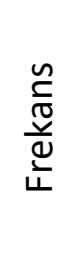 & $\frac{\frac{\pi}{\sigma}}{\frac{\pi}{0}}$ & 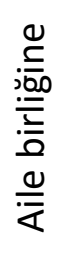 & 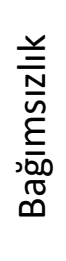 & $\underset{\infty}{\frac{m}{\pi}}$ & 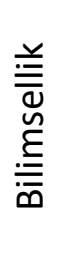 & 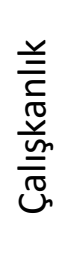 & 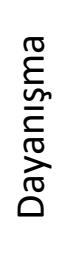 & 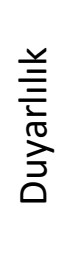 & 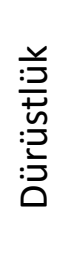 & 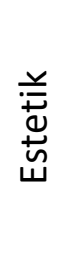 & 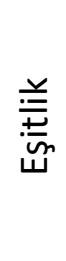 & 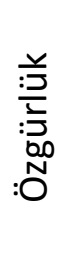 & 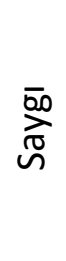 & बס & $\begin{array}{l}\frac{\text { J }}{J} \\
\frac{5}{\partial} \\
\frac{D}{0}\end{array}$ & 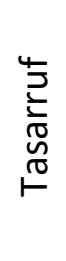 & 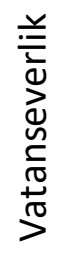 & 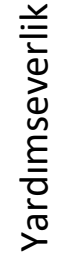 & $\frac{\frac{\varepsilon}{0}}{\frac{0}{0}}$ \\
\hline 5. & $f$ & 4 & 7 & 7 & 5 & 16 & 16 & 16 & 23 & 8 & 16 & 3 & 10 & 20 & 25 & 18 & 2 & 13 & 19 & 228 \\
\hline 6. & $f$ & 2 & 7 & 4 & 2 & 11 & 7 & 12 & 23 & 5 & 8 & 1 & 6 & 7 & 23 & 15 & 3 & 10 & 8 & 154 \\
\hline 7. & $f$ & 4 & 5 & 6 & 5 & 13 & 17 & 15 & 25 & 6 & 12 & 4 & 9 & 15 & 24 & 18 & 1 & 8 & 12 & 199 \\
\hline 8. & $f$ & 3 & 8 & 6 & 1 & 3 & 16 & 15 & 19 & 1 & 12 & 2 & 7 & 11 & 28 & 13 & 1 & 12 & 13 & 171 \\
\hline
\end{tabular}

Tablo 5 incelendiğinde $5^{\prime}$ inci sınıf düzeyinde 228, 6'ncı sınıf düzeyinde 154, 7'nci sınıf düzeyinde 199 ve 8'inci sınıf düzeyinde 171 değer bulgusuna ulaşılmıştır. Sınıf düzeyi açısından bakıldığında en fazla değere sahip olan kitabın 5.sınıf Türkçe ders kitabı olduğu görülmektedir. Ders kitaplarının hepsinde sevgi, sorumluluk, çalışkanlık, dayanışma, yardımseverlik değerlerinin fazla yer aldığı görülmektedir. Tasarruf, barış, adalet gibi değerlerin ise daha az olduğu tablodan anlaşılmaktadır.

\section{Sonuç, Tartışma ve Öneriler}

Bilgi ve teknoloji ile birlikte değişen ve gelişen dünyamızda bireylerin öz benliğini, millî kimliğini kaybetmeden değişime ve gelişmelere ayak uydurmasında aile ve eğitim kurumlarının sorumluluğu büyüktür. Toplumu bir arada ve ayakta tutan değerlerin çocuklara aktarılması elzemdir. Eğitim kurumlarında değerler aktarımının planlı ve düzenli bir şekilde temel becerilerle birlikte öğrencilere kazandırılması hedeflenmektedir. Türkçe dersi genel amaçları, vizyonu ve misyonu gereği öğrencilere dil becerilerini kazandırma ile birlikte öğrencileri duyuşsal yönden güçlendirmeyi, onlara millî, evrensel ve insanî değerleri aktarmayı da sağlamalıdır. Temel dil becerileri ve değerlerin öğrencilere kazandırılmasında Türkçe ders kitabı metinleri büyük bir araç konumundadır. Bu yönüyle ders kitabına seçilecek metinlerin niteliği önem arz etmektedir. Bu çalışmada da Türkçe ders kitabı metinleri değerler iletimi açısından incelenmiştir.

Türkçe ders kitaplarında, her sınıf düzeyinde 40 metin olmak üzere, toplam 160 metin bulunmaktadır. Bu metinlerin tamamı çalışmaya dâhil edilmiştir. En fazla değer bulgusuna 5.sınıf Türkçe ders kitabındaki metinlerde (f:228) rastlanılmıştır. 6.sınıf Türkçe ders kitabında 154, 7.sınıf Türkçe ders kitabında 199 ve 8.sınıf Türkçe ders kitabında 171 değer tespit edilmiştir. 5. Sınıf Türkçe ders kitabı metinlerinin değer açısından daha zengin olduğu söylenebilir. 
Türkçe ders kitapları metinleri arasında değerler iletimi açısından bir dengenin olmadığı da gözükmektedir. Benzer şekilde ders kitaplarındaki değerlerin dağılımında da bir dengenin gözetilmediği görülmektedir. 5.sınıf Türkçe ders kitabında sevgi (f:25), saygı (f:20), yardımlaşma (f:19); 6.sınıf Türkçe ders kitabında sevgi (f: 23), duyarlıık (f: 23), sorumluluk (f: 15); 7.sınıf Türkçe ders kitabında duyarlıık (f: 25), sevgi (f: 24), sorumluluk (f: 18), çalışkanlık (f: 17); 8.sınıf Türkçe ders kitabında sevgi (f: 24), duyarlıık (f: 19), çalışkanlık (f:16), dayanışma (f: 15) değerleri diğer değerlere göre daha fazla bulunmaktadır. Ders kitaplarında ise bazı değerlerin yok denecek kadar az olduğu görülmektedir. 5.sınıf Türkçe ders kitabında tasarruf (f: 2), eşitlik (f: 3 ), adalet (f: 4); 6.sınıf Türkçe ders kitabında eşitlik (f: 1), adalet (f: 2), barış (f: 2); 7.sınıf Türkçe tasarruf (f: 1), eşitlik (f: 4), adalet (f: 4); 8.sınıf Türkçe ders kitabında barış ( $f: 1$ ), dürüstlük ( $f: 1$ ) ve tasarruf (1) değerlerine metinlerde oldukça az yer verildiği bulgusuna ulaşılmıştır.

Alanyazında yapılmış çalışmalara bakıldığında da benzer bulgularla karşılaşmak mümkündür. Şen (2008) altıncı sınıf Türkçe ders kitabındaki metinleri değerler iletimi açısından incelediği çalışmasında, metinlerin belirlenen değerleri iletmede yetersiz kaldığını tespit etmiştir. Değerlerin dağılımında da bir dengenin olmadığı görülmüştür. Sevgi, saygı, duyarlılık, vatanseverlik ve sorumluluk değerlerine diğer değerlere göre fazla yer verildiği tespit edilmiştir. Bazı değerlere ise hiç yer verilmediği görülmüştür. Elde edilen bulgular, çalışmamızda elde edilen bulgularla benzerlik göstermektedir. Doğan ve Gülüşen (2011) de yaptıkları araştırmada 6, 7. ve 8.sınıf Türkçe ders kitaplarını değerler iletimi açısından yetersiz bulmuşlardır. Toplam 111 metnin 44'ünde belirlenen herhangi bir değer bulgusuna rastlamamışlardır. Değerlerin de konulara göre düzensiz dağıtıldığı görülmüştür.

Fırat ve Mocan (2014) Türkçe ders kitabındaki hikâye metinlerini değerler aktarımı açısından incelemişlerdir. Hikâyelerde milli değerlerin yok denecek kadar az olduğu görülmüştür. Pilav ve Erdoğan (2016) ise Türkçe ders kitabındaki bilgilendirici metinler üzerinde yaptıkları çalışmalarında, bütün sınıf seviyelerinde sevgi ve ulusal değerlere sıklıkla yer verildiğini tespit etmişlerdir. Ancak 6.sınıf Türkçe ders kitabında sabırlı olmak, arkadaşlık ve kanaatkâr olma; 7.sınıf Türkçe ders kitabında hoşgörü, misafirperverlik ve kanaatkâr olma; 8.sınıf Türkçe ders kitabında yardımlaşma değerlerine çok az yer verildiği görülmüştür. 5, 6, 7. ve 8.sınıf düzeyi ders kitaplarındaki bilgilendirici metinlerde çok fazla sayıda değere rastlanılmadığı da araştırmanın bulguları arasında yer almaktadır. Deniz ve Karagöl (2018) 5. ve 6.sınıf Türkçe ders kitaplarında değerlerin dengeli bir şekilde dağılmadığını tespit etmişlerdir. Sevgi ve dostluk değerlerine daha fazla yer verildiği görülmüştür. İlkokul Türkçe ders kitapları üzerinde yapılan bir çalışmada da en fazla sevgi, dayanışma ve çalışkanlık değerlerin yoğun olarak bulunduğu görülmüştür (Yılar, 2016) 
Türkçe ders kitapları üzerinde farklı zamanlarda yapılan çalışmaların neredeyse tamamında, metinlerin değer aktarımında yetersiz kaldığı, değerlerin dağılımında da bir dengenin olmadığı görülmektedir. Çalışmamızdan elde edilen bulgular ile alanyazındaki çalışmaların bulguları benzerlik göstermektedir. Çeşitli değerleri işleyen nitelikli ve öğrencide davranış değişikliği oluşturabilecek etkide metinler ders kitabına seçilmelidir. Ders kitaplarının değerler eğitimi açısından daha nitelikli hale getirilmesi gerekmektedir. Alanyazından ve çalışmamızın bulgularından hareketle şu önerilere yer verilebilir:

- Türkçe Dersi Öğretimi Programı́nda değerlerin temel dil becerileri ile birlikte kazandırılacağı ifade edilmekte ancak bu değerlerin nasıl kazandırılacağı ile ilgili yeterli bilgi bulunmamaktadır. Programda bu değerlerin hangi yöntem ve tekniklerle kazandırılacağı belirtilmelidir.

- Temel dil becerilerinde olduğu gibi değerlerin de sarmal bir şekilde okulöncesinden itibaren yapılandırılması gerekir.

- Temel öğrenme alanları gözetilerek hangi sınıf seviyesinde hangi değerlerin aktarılacağı belirlenmelidir.

- Türkçe ders kitabı metinlerinin seçiminde özen gösterilmeli, çocuk edebiyatının temel ilkesi olan çocuğa görelik ilkesi göz önünde bulundurulmalıdır. Sanatçı duyarlıı̆̆ıyla oluşturulmuş nitelikli yapıtlar, öğrencilerle buluşturulmalıdır. Öğrencilerin ilgi ve gereksinmeleri doğrultusunda seçilmiş metinlerle değerler aktarımı daha etkili olacaktır.

- Değerler, öğrencilere empoze edilmemeli, yazınsal nitelikli metinlerle sezdirilmeli ve duyumsatılmalıdır.

- Değerlerin kazandırılmasında ailenin rolü çok önemlidir. Bu nedenle ailenin desteği sağlanmalıdır.

\section{Kaynaklar}

Akbaş, O. (2004). Türk millî eğitim sisteminin duyuşsal amaçlarının (değerlerinin) ilköğretim Il. kademedeki gerçekleşme derecesinin değerlendirilmesi. Yayımlanmamış Doktora Tezi, Gazi Üniversitesi Eğitim Bilimleri Enstitüsü, Ankara.

Bacanlı, H. (1999). Gelişim ve öğrenme (2. Baskı). Ankara: Nobel Yayın Dağıım.

Bilgin, N. (1995). Sosyal psikolojide yöntem ve pratik çalışmalar. İstanbul: Sistem Yayınclık.

Bilgin, N. (2000). İçerik analizi. İzmir: Ege Üniversitesi Edebiyat Fakültesi Yayınları.

Büyüköztürk, Ş., Kılıç Çakmak, E., Akgün, Ö. E., Karadeniz, Ş. ve Demirel F. (2015). Bilimsel araştırma yöntemleri (19. baskı). Ankara: Pegem Akademi.

Çelikpazu, E. E. ve Aktaş, E. (2011). MEB 6. 7 ve 8. sınıf Türkçe ders kitaplarında yer alan metinlerin değer iletimi açısından incelenmesi. Turkish Studies - International Periodical For The Languages, Literature and History of Turkish or Turkic Volume 6/2 Spring 2011, p. 413-424. 
Çırak, G. vd. (2014). 5. sınıf Türkçe ders kitabındaki metinlerin ilettiği değerler açısından incelenmesi. Mediterranean Journal of Humanities mjh.akdeniz.edu.tr IV/1, 83-95.

Deniz, K. ve Karagöl, E. (2018). Değerler eğitimi açısından ortaokul Türkçe ders kitapları. Karaelmas Journal of Educational Sciences, 1, 244-255.

Doğan, B. ve Gülüşen, A. (2011). Türkçe ders kitaplarındaki metinlerin değerler bakımından incelenmesi. Sosyal Bilimler Dergisi, Cilt 1, Sayı 2, 75-102.

Ekiz, D. (2015). Bilimsel araştırma yöntemleri. Ankara: Anı yayıncılık.

Fırat, H. ve Mocan, A. (2014). Türkçe ders kitaplarındaki hikâyelerde yer alan değerler. Türkiye Sosyal Araştırmalar Dergisi, 183, 25-49.

Izgar, G. (2013). ilköğretim okulu 8. sınıf öğrencilerine uygulanan değerler eğitimi programının demokratik tutum ve davranışlarına etkisi. Yayımlanmamış Doktora Tezi, Necmettin Erbakan Üniversitesi Eğitim Bilimleri Enstitüsü, Konya.

İscan, C. D.(2007). Ilköğretim düzeyinde değerler eğitimi programının etkililiği. Yayımlanmamış Doktora Tezi, Hacettepe Üniversitesi Sosyal Bilimler Enstitüsü, Ankara.

Karasar, N. (2017). Bilimsel araştırma yöntemi. Ankara: Nobel Yayın Dağıtım.

Kurtdede-Fidan, N. ve Öner, Ö. (2018). Değerler eğitimine yönelik yapılan lisansüstü tezlerin incelenmesi, International Journal of Field Education, 4(1), 1-17.

Lickona, T. (1991). Educating For Character: How Our Schools Can Teachrespect And Responsibility. Newyork: Bantam Books.

MEB Türkçe Dersi Öğretim Programı (TDÖP) (illkokul ve Ortaokul 1, 2, 3, 4, 5, 6, 7 ve 8. Sınıflar) (2018). 17.03.2019 tarihinde http://mufredat.meb.gov.tr/ProgramDetay.aspx?PID=332'den erişildi .

MEB Sosyal Bilgiler Dersi Öğretim Programı (SDÖP) (ilkokul ve Ortaokul 4, 5, 6 ve 7. Sınıflar) (2018). 17.03.2019 tarihinde http://mufredat.meb.gov.tr/ProgramDetay.aspx?PID=354'den erişildi.

Pilav, S. ve Erdoğan Ş. (2016). Ortaokul Türkçe ders kitaplarındaki bilgilendirici metinlerin değer iletimi açısından incelenmesi. Millî Eğitim Dergisi, 210, 351-371.

Pilav, S. ve Demir, H. ve Demir H.A.(2015). Illköğretim 7. sınıf Türkçe ders kitaplarındaki okuma metinlerinin değer iletimi açısından incelenmesi. Milli Eğitim Dergisi, Cilt 44, Sayı 206. 16-29.

Rokeach, M. (1973). Nature of human values. New York: The Free Press.

Öncül, R. (2000). Eğitim ve eğitim bilimleri sözlüğü, İstanbul: Milli Eğitim Basımevi.

Öztürk Samur, A. (2011). Değerler eğitimi programının 6 yaş çocuklarının sosyal ve duygusal gelişimlerine etkisi. Doktora Tezi, Selçuk Üniversitesi Sosyal Bilimler Enstitüsü, Konya.

Schwartz, S. H. (1992). Universals in the content and structure of values: theorotical advances and empirical tests in 20 countries. Advances in Experimental Social Psychology. 25, 1-65.

Sever, S., Kaya, Z. ve Aslan, C. (2013). Etkinliklerle Türkçe öğretimi. İzmir: Tudem Yayınları.

Şen Ü. (2008). Altıncı sınıf Türkçe ders kitaplarındaki metinlerin ilettiği değerler açısından incelenmesi, Uluslararası Sosyal Araştırmalar Dergisi, 1(5), 763-779.

Tavşancıl, E. ve Aslan, A. E. (2001). Sözel, yazılı ve diğer materyaller için içerik analizi ve uygulama örnekleri. İstanbul: Epsilon Yayıncılık.

TDK Türkçe Sözlük.(2011). Türk Dil Kurumu Yayınları, Ankara.

Tulunay Ateş, Ö. (2017). Türkiye'de değerler eğitimi uygulamalarının öğrencilere kazandırılması istenen olumlu özellikler üzerindeki etkisi. Değerler Eğitimi Dergisi Cilt 15, No. 34, 41-60, 
Yılar, R. (2016). Illettiği değerler açısından ilkokul Türkçe ders kitaplarındaki metinler üzerinde incelemeler. Bayburt Eğitim Fakültesi Dergisi, Cilt: 11 Sayı: 2, 490-506.

Yıldırım, A. ve Şimşek, H. (2013). Sosyal Bilimlerde Nitel Araştırma Yöntemleri. Ankara: Seçkin Yayıncılık.

\section{İncelenen Ders Kitapları}

Haykır, H.A. vd. (2018). Ortaokul ve imam hatip ortaokulu Türkçe ders kitabı 5. Ankara: Milli Eğitim Bakanlığı Yayınları.

Şekerci, Y. (2018). Ortaokul Türkçe ders kitabı 6. İstanbul: Eksen Yayıncılık.

Kaya, B. (2018). Ortaokul ve imam hatip ortaokulu Türkçe ders kitabı 7. Ankara: Dersdestek Yayıncılık.

Mete, G. vd. (2018). Ortaokul ve imam hatip ortaokulu Türkçe ders kitabı 8. Ankara: Milli Eğitim Bakanlığı Yayınları.

\section{Extended Abstract \\ Introduction}

In addition to improving students' comprehension and expression skills, Turkish language teaching aims to acquire national consciousness and internalize universal values by using modern teaching approaches, methods and techniques in teaching and learning processes. When curriculum is considered, it is seen that individuals who have knowledge, skills and behaviors integrated with national values and competencies are required to be trained. It is a fact that the future of a society depends on the growth of individuals who adapt their values and apply them to the competencies they have.

The purpose of this study is to examine the texts in the secondary school Turkish coursebooks in terms of the transmission of values and to determine the distribution of the transmitted values in the coursebooks of the 5 th, 6th, 7th and 8th grades.

\section{Method}

This study is structured upon a descriptive model. It includes the 5th, 6th, 7th and 8th grade Turkish coursebooks. Coursebook for the 5th and 8th grades is published by the Ministry of National Education for the secondary schools, for the 6th grade is published by Eksen publication and for the 7th grade is published by Dersdestek publication. In this study, document analysis method is used. Turkish coursebook texts which are included in the study are examined according to the erek Values Examination Form, and the values are determined accordingly.

Result and Discussion

160 texts were found in Turkish coursebooks. All of these texts were included in the study. The highest frequency was found in the 5th grade Turkish coursebook (f: 228). In the 6th grade Turkish coursebook 154 frequency, in the 7th grade 199 frequency, and in the 8th grade 171 frequency of values were determined. It can be concluded that the coursebooks of 5th Grade Turkish coursebooks are richer in terms of values. There was also a lack of balance between the frequency of values in the Turkish coursebooks. Similarly, a balance was not observed in the distribution of the values within each coursebook. In the 5th grade Turkish coursebook, love ( $f$ : $25)$, respect (f: 20$)$, cooperation (f: 19); in the 6th grade Turkish coursebook, love (f: 23), sensitivity (f: 23), responsibility (f: 15$)$; sensitivity ( $f: 25)$, love (f: 24$)$, responsibility (f: 18$)$, diligence (f: 17$)$; in 7 th grade Turkish coursebook; in the 8th grade Turkish coursebook, love ( $f: 24)$, sensitivity (f: 19), diligence ( $f: 16)$, and solidarity ( $f$ : $15)$ were observed higher than the other values. In coursebooks, some values were neglected. In the 5th Turkish coursebook saving (f: 2 ), equality (f: 3 ), justice (f: 4$)$; in the 6th grade Turkish coursebook equality (f: 1 ), justice (f: 2 ), peace (f: 2 ); in the 7 th grade Turkish savings (f: 1 ), equality (f: 4), justice (f: 4); in the 8th grade Turkish coursebook, peace ( $f: 1)$, honesty (f: 1 ) and saving (1) values were found to be quite rare in the texts. 


\section{Ekler}

\section{Ek-1: 5.Sınıf Türkçe Ders Kitabında Yer Alan Metinler}

1-Oyuncak, 2-Çocukluk, 3-Ben Bir Çınar Ağacıydım, 4-Anlamak, 5-Güneşin Uyuduğu Yer, 6Bilmeyen Var Mı?, 7-Mustafa Kemal'in Kağnısı, 8-15 Temmuz, 9-Dersimiz Atatürk, 10-Küçük Ağa, 11Güvercin, 12-Karagöz ile Hacivat- İncelik, 13-Püf Noktası, 14-Adsız Çeşme, 15-Vakit Varken, 16-Uzayda Bir Gün, 17-Sarımsak Soslu Makarna, 18-Bir Dâhiyle Konuşmak, 19-Sanki Caminin Bakım Kılavuzu, 20Jules Verne'den Geleceğe Dair, 21-Anadolu Sevgisi, 22-Forsa, 23-Tamburi Cemil Bey Enstrümanları Anlatıyor, 24- Dede Korkut-Boğaç Han, 25-Çocuk Doğru Söyledi, 26-Okuma Kitaplarım, 27-Kitabın Serüveni, 28-Karikatür, 29-Küçük Şeylerin Hikayesi, 30-Keramet Kabukta Mı?, 31-Anadolu'nun Cirit Oyunları, 32-Sağlıklı Yaşıyorum, 33-Cazgır, 34-Bilinçsiz illaç Kullanımı, 35-Hasta, 36-Yüksek Evde Oturanın Türküsü, 37-Reçete, 38-Kar Tanesinin Serüveni, 39-Kuş Ağacı, 40-Eyvah! Ormanda Kayboldum.

\section{Ek-2: 6. Sınıf Türkçe Ders Kitabında Yer Alan Metinler}

1-Forsa, 2-Kaynatılmış Tohum, 3-Ceylana Yardım Edenler, 4-Adsız Çeşme, 5-Dostluk, 6-Nevruz, 7-Türküler Dolusu, 8-Boş Bir Kümes, Birkaç Dolu Kalp, 9-Bayrak, 10-Önce İğneyi Kendine Batır, Sonra Çuvaldızı Ele, 11-Atatürk Orman Çiftliği, 12-Atatürk Geometri Kitabı Yazmış, 13-30 Ağustos, 14-Ankara Türk Odası, 15-Dolunayda Kurtlar, 16-Nasrettin Hoca Fıkraları, 17-Ben Kimim?, 18-Bilmece, 19Kentlerde Yaşayan Çocuklar da Oyun Oynamak İster, 20-Çocuk ve Resim, 21-Birlikte, 22-Geri Kazanım, 23-Ömür Törpüsü, 24-Sihirli Pasta, 25-Değerlere Uymada Üç Hata, 26-Güler Yüze ve Gülmeye Dair, 27Teknolojik Bayram Kutlamaları, 28-Pulsuz Dilekçe, 29-Bilgilenirken Medya, 30-Bilinçli Medya Tüketimi, 31-Uzaklar, 32-Gezegenimiz Isınıyor, 33-Orman, 34-Beyaz Diş, 35-Gün Doğuyor, 36-Uçakla Yolculuk, 37-Robotik ile Enerji, 38-Newton'un Elması, 39-Bilimsel Araştırma Yaparken Nelere Dikkat Etmeliyiz?, 40-Mikrop Savaşları.

\section{Ek-3: 7. Sınıf Türkçe Ders Kitabında Yer Alan Metinler}

1-Mor Salkımlı Ev, 2-Sevgi Kurtaracak Bizi, 3-Kırmızı Pabuçlar, 4-İnsanlığın Cesaret ve Onur Simgesi: Helen Keller, 5-iki Anı, 6- Yer Çekimsiz Yaşam, 7-Rüzgar, 8-Yeşil Gözlü Kardan Adam, 9-Doğa ve İnsan, 10-Beyaz Gemi, 11-Ülkemin Renkli Haritası, 12-Dünyayı Güldüren Adam, 13-Bayrak, 14Bilmece, 15-Anadolu'da Kilim Demek, 16-i̇stanbul Liseli Küçük Hasan, 17-Mustafa Kemal'in Kağnısı, 18Atatürk'ün Kişiliği ve Özellikleri, 19-15 Temmuz Şehitlerinin Adları Okullarda Yaşatılıyor, 20-Samsun Yolculuğuna Hazırlık, 21-Ak Sakallı Bilge Dede, 22-Yemeğin Buharını Yiyen, Ücretini Para Sesi Olarak Öder, 23-Sorumluluklarımız, 24-Harman Yerinde, 25-Vaktini Boş Geçirme, 26-Gool!, 27-Benim Adım: Şeker Çocuk, 28-Yeterli ve Dengeli Beslenme, 29-Hastahane, 30-ìyi Uykular... Tatlı Rüyalar..., 31-Belkıs Tiyatrosu, 32-Geleneksel El Sanatları Çarşısı, 33-Müzik, İnekler, Çiçekler ve Başka Şeyler, 34- Ay Şairi, 
Türkçe Ders Kitaplarındaki Metinlerin İlettiği Değerler Açısından İncelenmesi

35- Leyla Gencer, 36-Buluşa Doğru, 37-Kara Tren, 38-Medya Yalnızca Televizyon ve Gazeteden İbaret Değildir, 39-Tatent, 40-iğnenin Deliği.

Ek-4: 8. Sınıf Türkçe Ders Kitabında Yer Alan Metinler

1-Benlik Üzerine, 2-Martı, 3-Acele Karar Vermeyin, 4-Güler Yüz, 5- Bir Adım Atın, 6-Vatan Yahut Silistre, 7-O geliyor, 8-i̇stiklal Madalyası, 9-Kahramanların Dilinden 15 Temmuz, 10-Atatürk'e Mektup, 11-Faydalı Bir İş görmek Zevki, 12-Gurbet, 13-Türkçenin Güzelliği, 14-Çocuk ve Ekmek, 15-Yirmi Beş Kuruş, 16-Sanat, 17-Mikro Minyatür, 18-Selimiye Camii, 19-Bir Kış Öyküsü, 20-Bir Baba/Bir Zihniyet, 21Anadolu Uygarlıkları, 22-Burada Dur, 23-Ergenekon Destanı, 24-Türklerde Toylar, Merasimler, Festivaller ve Şenlikler, 25-Anadolu Davulu, 26-Kalbin Sesi, 27-Geçen Zaman, 28-Değirmende Döner Taşım, 29-Satııık Ev, 30-Bursa'da Zaman, 31-Yunus Emre'nin Mezarları, 32-Gülü İncitme Gönül, 33Emine Teyze'nin Çilek Reçeli, 34-Yürekdede ile Padişah, 35-Eşekle Tilki, 36-Bilge Adamın Yolu, 37-Aliya İzzetbegoviç ve Özgürlük Mücadelesi, 38-Özgürlük, 39-Burada Bülbül Ağlamış, 40-Haritada Bir Nokta. 